Global Journal of Business and Social Science Review

Journal homepage:

Global J. Bus. Soc. Sci. Review 7 (2) 151 - 157 (2019)

\title{
Intermediary Effect of Intention of ICT adoption on the Relationship of Attitudes toward Adoption and Adoption of VLE among the Malay Language Teachers
}

\author{
Chew Fong Peng, ${ }^{1} *$ Zanariah Hamid, $^{2}$ Mohd. Shahril Nizam ${ }^{3}$ \\ ${ }^{1.3}$ Senior lecturer, Faculty of Education, University of Malaya, 50603, Kuala Lumpur, Malaysia \\ ${ }^{2}$ Teacher, Kepong National Secondary School, Selangor, Malaysia
}

\begin{abstract}
Objective - This research aims to explore whether the intention of ICT adoption in teaching Malay language acts as a mediator in the relationship between attitudes toward ICT adoption and the adoption of the Virtual Learning Environment (VLE) among secondary school Malay Language teachers.

Methodology/Technique - TAM is the basis theory in this quantitative study which uses a questionnaire to collect the data. The population of the study comprises of 410 secondary school teachers in Selangor by applying various probability sampling procedures. The research instrument was adapted from a previous questionnaire and pilot study which shows an alpha Cronbach at .81. Software of Smart-PLS was used to analyse the results of the study.

Findings - The mediator analysis showed a positive and significant direct relationship $(\beta=.067$, p <.05) between attitude and the adoption of VLE. The findings obtained in the analysis of indirect relationships and direct relationships clearly indicate that the intention of ICT adoption acts as partial mediator if the impression of indirect contact with the effects of direct relationships was significant.

Novelty - In summary, the significant relationship between attitudes toward adoption and the intention of ICT adoption and adoption of VLE suggest that intention acts as a mediator.
\end{abstract}

Type of Paper: Empirical.

Keywords: Attitude; ICT Adoption; Malay Language; Secondary School; Virtual Learning Environment.

Reference to this paper should be made as follows: Peng, C. F.; Hamid, Z.; Nizam, M. S. (2019). Intermediary Effect of Intention of ICT adoption on the Relationship of Attitudes toward Adoption and Adoption of VLE among the Malay Language Teachers, Global J. Bus. Soc. Sci. Review 7 (2): 151 - 157 https://doi.org/10.35609/gjbssr.2019.7.2(6)

JEL Classification: A20, A29, M15, I23.

\section{Introduction}

In Malaysia, Malay is the official language, National Language and compulsory subject that must be passed by all students. In Malay Language classrooms, ICT element is included in the Standard Curriculum of Primary and Secondary Schools (Malaysian Ministry of Education, 2003).

\footnotetext{
* Paper Info: Revised: March 11, 2019

Accepted: June 21, 2019

* Corresponding author: Chew Fong Peng

E-mail: fpchew@um.edu.my

Affiliation: Faculty of Education, University of Malaya, Malaysia
} 
The Ministry of Education has invested considerable capital in an effort to enhance the use of ICT in teaching and learning throughout the country. One of the current ICT programs implemented in all national schools is the Virtual Learning Environment (VLE). VLE as a teaching aid which can be used to bring fun to students in learning (Afzan, Abdullah, Alif \& Yusoff, 2014). However, an Audit Report of 2013 indicates that the use of the VLE based on student logins was between $.17 \%$ to $.63 \%$ while teachers was between $57 \%$ to $4.69 \%$. These results are relatively low when compared to the expenses incurred for license and maintenance of VLE that exceeds 500 million Malaysian Ringgit (Ministry of Finance Malaysia, 2014).

According to Rienties et. al. (2016), the main cause of non-use of this technology in schools is due to the refusal of teachers to accept the use of the technology in teaching. This attributes to the teachers' attitude in the use of technology (Yanti, Setiawan, Nurhabibah, \& Yannuar, 2018). The issue of teacher acceptance regarding the use of technology is related to the teacher's response to the usability and ease of use of the technology. Therefore, it is important to investigate the adoption of the VLE among Malay Language teachers as the level of adoption is an important indicator of the success of VLE.

Attitudes toward the use of VLE and teachers' adoption the use of technology will influence their intention of ICT adoption. Hence, the researchers suggest that the variable of intention be measured as a mediator to identify the relationship between attitudes toward adoption and the adoption of virtual learning environment among secondary school Malay language teachers in Malaysia.

On the other hand, local studies concerning VLE in the context of teaching are still very limited, and have nothing to do with teachers generally or Malay language teachers in particular. Previous studies on computer use tends to focus on Mathematics, Science and English (Ilyani et. al., 2012). Moreover, studies on the use of VLE in secondary schools are still lacking (Rosemaliza, Azwani \& Nur Sakinah, 2016).

Therefore, the research question in this study can be framed as follows: "Does intention to adopt ICT in teaching Malay language act as a mediator in the relationship between attitudes toward ICT adoption with the adoption of the VLE Frog among the secondary school Malay language teachers in Selangor?" The hypothesis is stated as follows: "The intention to adopt a role as an intermediary in the relationship between attitudes toward adoption with the adoption of the Virtual Learning Environment among Malay Language teachers in Selangor".

This paper begins with a literature review, followed by the research methodology, results, a discussion, and a conclusion.

\section{Literature Review}

Attitudes towards the use of technology is defined by Davis (1989) as a positive or negative feeling of the individual who uses a technology system. This is due to the TAM's theory which indicates that positive attitudes affect individual behavior towards the use of technology (Averweg, 2008; Alzaidiyeen, 2017).

The success of using and integrating technology in teaching requires teachers to be positive (Farid, 2016). Tezci (2010) found that teachers' attitude towards computers had a positive and significant relationship with computer usage $(r=.332, p<.01)$ and Internet usage $(r=.232, p<.01)$. However, research by Yeou (2016) found that attitude has no positive or significant relationship with the frequency of the use of Moodle $(\beta=$ $.18, \mathrm{p}>.05)$.

Wong (2016) states that the variable of use desire is defined as behavioral intention to use technology in teaching. The studies that show a positive and significant relationships between desire variable and actual use was found by Baleghi-Zadeh, Ayub, Mahmud and Daud (2017) $(\beta=.55, \mathrm{p}<.00)$, May, Ramayah and Abang Azlan (2015) $(\beta=.69, \mathrm{p}<.00)$. Sumak and Sorgo (2016) indicate that users have no significant relationship before using technology $(\beta=.20, p>.05)$, but significant for the users after using technology $(\beta=.32, p$ $<.001)$. The relationship of the use of ICT with the intention to use was based on the idea that each individual has an intention to do behavior even if the individual has a negative attitude (Bajaja \& Nidumolu, 1998).

Davis (1989) defines actual use as a valuation in the form of measurements of the frequency and duration of technology used. If a technology improves workability and is easy to use, users will often be comfortable

Global J. Bus. Soc. Sci. Review 7 (2) $151-157$ (2019) 
using the technology. Tutik, Astuti and Farah (2012) conducted a study on the actual use of technology by applying the TAM theory. The findings report that intention has a significant relationship with actual use ( $\beta=$ $.437, \mathrm{p}<.05)$ and attitude has no significant relationship with intention $(\beta=.158, \mathrm{p}>.05)$. On the other hand, May et. al. (2015) found that intention has a significant and positive relationship with the use of technology $(\beta=.694, p<.01)$.

\section{Research Methodology}

This study applies a quantitative approach which uses a questionnaire to collect the data.

\subsection{Theoretical Framework}

TAM is the basis of the adoption of the VLE Frog in teaching Malay Language. The Technology Acceptance Model (TAM) was pioneered by Davis (1989). Teachers with positive attitudes towards elearning have a high level of acceptance compared to teachers who have negative attitudes toward e-learning (Al-alak \& Alnawas, 2011), whereas the use of technology is influenced by the desire to use technology (Behavioral Intention).

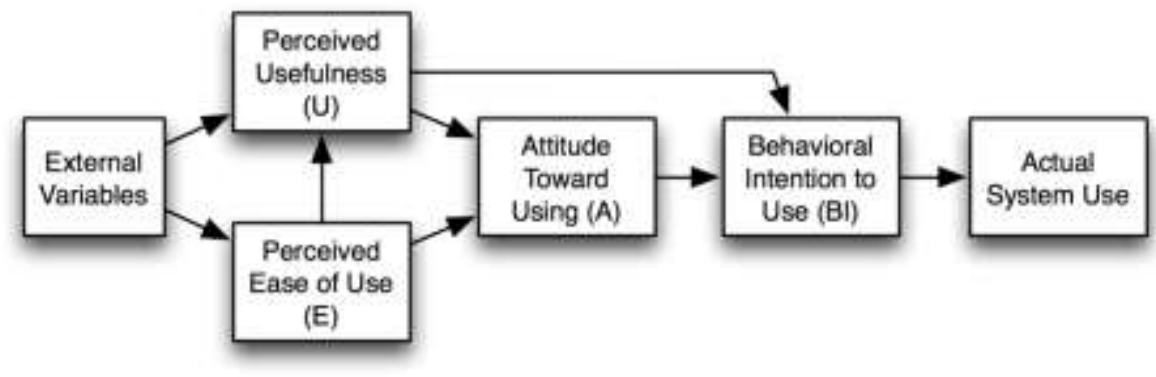

Figure 1. Technology Acceptance Model (TAM)

(Source: Davis, Bagozzi and Warshaw, 1989)

\subsection{Sample and Sampling Methods}

The population of the study comprises of National Secondary School teachers in Selangor. The Krejcie and Morgan Table and the G-Power 3.1 software were used to determine the number of teacher respondents. In addition, a proportional technique was used to determine the number of teachers involved in each district of Selangor, resulting in the identification of 82 secondary schools from which respondents were randomly selected, forming a total of 410 National Secondary School Malay Language teachers.

\subsection{Instrument of the Study}

The research instrument consists of four parts which was adapted from previous questionnaires. Part A is the demography of the respondents, part $\mathrm{B}$ is the attitudes towards adoption ( 7 items) which was adapted from Teo and Zhou (2016), part C is the intention for adoption (7 items) which was adapted from Fathema, Shannon and Ross (2015), while part D is technology adoption (10 items) which is taken from Davis, et. al. (1989). The instrument was verified by field experts and the pilot study showed an alpha Cronbach of .81. Software of Smart-PLS was used to analyze the results of the study. 


\section{Results}

Table 1. Analysis of Intention of ICT Adoption as a Mediator between the Relationship of Attitudes toward Adoption and the Adoption of VLE

\begin{tabular}{|c|c|c|c|c|c|c|}
\hline \multirow[t]{2}{*}{ Relationship } & \multirow[t]{2}{*}{$\beta$} & \multirow[t]{2}{*}{ SD } & \multirow[t]{2}{*}{$\mathrm{t}$} & \multirow[t]{2}{*}{$\mathrm{p}$} & \multicolumn{2}{|c|}{$\begin{array}{l}\text { Confidence } \\
\text { Interval Bias } \\
\text { Corrected }\end{array}$} \\
\hline & & & & & LL & UL \\
\hline $\begin{array}{l}\text { Path a } \\
\text { Attitude } \rightarrow \text { intention of ICT adoption }\end{array}$ & .224 & .050 & 4.517 & $.000^{*}$ & .108 & .315 \\
\hline $\begin{array}{l}\text { Path b } \\
\text { Intention of ICT adoption } \rightarrow \text { adoption }\end{array}$ & .350 & .029 & 12.055 & $.000 *$ & .297 & .400 \\
\hline $\begin{array}{l}\text { Direct Path c } \\
\text { Attitude } \rightarrow \text { adoption }\end{array}$ & .067 & .027 & 2.484 & $.015^{*}$ & .005 & .107 \\
\hline $\begin{array}{l}\text { Indirect Effect (axb) } \\
\text { Attitude } \longrightarrow \text { intention of ICT adoption } \\
\text { adoption } \rightarrow\end{array}$ & .079 & .018 & 4.326 & $.000^{*}$ & .046 & .116 \\
\hline
\end{tabular}

Note: $* p<.05$

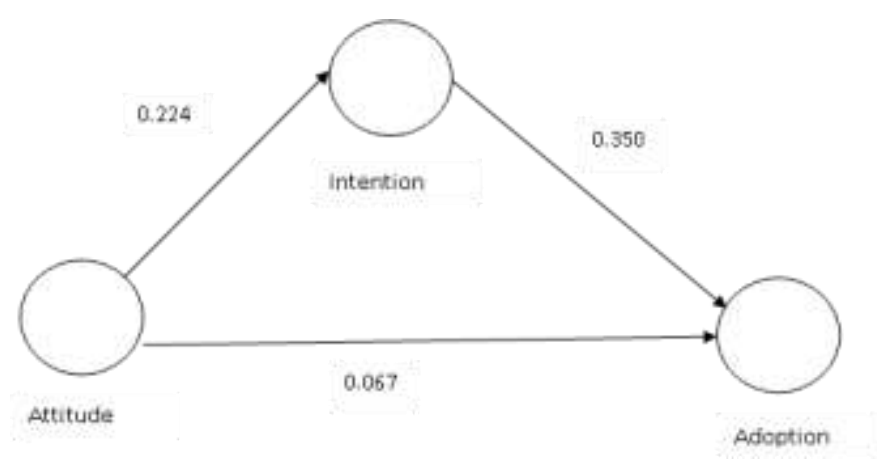

Figure 2. Model of Intention of ICT Adoption as Mediator between the Relationships of Attitudes towards Adoption and the Adoption of VLE

After the bootstrapping analysis was carried out, the indirect effect of the relationship between attitudes towards adoption and the intention for the adoption and adoption indicated a coefficient value at $\beta=.079, \mathrm{p}$ $<.05$, which is significant. In addition, the lower value and the value of the effect of the indirect relationship of $95 \%$ corrected bias did not show a value of $0(\mathrm{LL}=.056, \mathrm{UL}=.116)$. These findings explain that the intention for adoption acts as a mediator.

The next mediator analysis procedure was conducted to determine the direct relationship between attitude and the adoption of VLE which also recorded a positive and significant relationship $(\beta=.067, p<.05)$. The findings obtained in the analysis of the indirect relationships and direct relationships clearly indicate that the intention for adoption acts as a partial mediator if the impression of indirect contact with the effects of direct relationships was significant.

In summary, the relationship between attitudes toward adoption and the significant intention for adoption and adoption suggests that it acts as a mediator. Therefore, the hypothesis is accepted. 


\section{Discussion}

This study shows that the intention of ICT adoption acts as a partial mediator in the relationship between attitude towards adoption and the adoption of VLE. Positive and significant relationships between the two effects of indirect effects and the direct effect suggest that a positive attitude of the teachers will lead to an increase in the adoption of VLE. At the same time, teachers' positive attitudes toward adoption will also increase their willingness to adopt VLE. These findings also imply that attitude serves as a partial mediator. It is clear that the adoption of VLE among Malay language teachers in Selangor is partly explained by the teachers' intention to adopt ICT.

The findings of this study are parallel to the previous study when the variable of behavioral intentions act as a mediator between attitudes toward adoption and the behavior in the Designed Behavioral Theory (TPB) (Ajzen, 1987). Similarly, the views of some other researchers that the intention to act as a mediator between attitude toward adoption and behavior (Kim \& Hunter 1993, (E-tax) usage. However, this study is similar to the findings of Moya et. al's (2016) study when it comes to the intention for adoption to act as a partial mediator between attitudes toward adoption and the adoption of VLE.

In terms of mediator type, this study is different from previous studies. Moya, Nabafu, Maiga and Mayoka (2016) indicate the intention to be a partial mediator between attitude and technology of VLE. The schools also need to ensure that teacher's positive intention and attitude towards adoption exists among Malay language teachers to enable the adoption of VLE.

The main contribution of this study is to the Malaysian Ministry of Education (MOE) as the policy maker. MOE may devise strategies to increase the adoption of VLE through variables that affect use (Ansong, Boateng \& Boateng 2017). This study is also expected to help to increase the applicability of this model in the teaching and learning process because use of the VLE gives a variety of benefits to the teaching of Malay language and is beneficial to the students.

\section{Conclusion}

In conclusion, this study identifies the intermediary effect of intention for ICT adoption on the relationship of attitudes and the adoption of VLE among the secondary school Malay language teachers in Malaysia generally. This fills the gap left by previous studies that focus only on lecturers in universities, preservice teachers in schools, university and school students in terms of use of ICT. Therefore, the model in this study may fulfil the needs of government, schools, and teachers to enhance ICT adoption in teaching Malay language. Increment in Malay language achievement will effect overall performance of students because Malay language is the medium of instruction in all national schools in Malaysia.

This model is expected to be applied not only to the population, but to all National Secondary School Malay language teachers in Malaysia as well as to add value to the research related to the adoption of the VLE. This study is also expected to help to increase the applicability of the VLE in teaching and can be used by students. This is because the use of the VLE has considerable benefits to the teaching of Malay language and is beneficial to students.

\section{References}

Ajzen, I. (1987). Attitudes, Traits, and Actions: Dispositional Prediction of Behavior in Personality and Social Psychology. Advances in Experimental Social Psychology, 20(1), 1-63.DOI: 10.1016/S0065-2601(08)60411-6.

Al-alak, B. A. and Alnawas, I. A. M. (2011). Measuring the Acceptance and Adoption of E-Learning by Academic

Staff. Knowledge Management and E-Learning: An International Journal, 3(2), 201-220. DOI=10.1.1.705.2780\&rep=rep1\&type=pdf.

Ansong, E., Boateng, S. L., \& Boateng, R. (2017). Determinants of E-Learning adoption in universities: Evidence from a developing country. Journal of Educational Technology Systems, 46(1), 30-60. https://doi.org/10.1177/0047239516671520 
Alzaidiyeen, N.J. (2017). English as a Foreign Language Students Attitudes towards the Utilization of iPad in Language Learning. Malaysian Online Journal of Educational Technology, 5(3), 16-24. https://files.eric.ed.gov/fulltext/EJ1150412.pdf

Averweg, U. R. (2008). Information Technology Acceptance in South Africa: An Investigation of perceived usefulness, perceived ease of use and actual system use constructs. The African Journal of Information Systems, 1(1), 44-66. https://digitalcommons.kennesaw.edu/cgi/viewcontent.cgi?article=1004\&context=ajis

Bajaja, A., \& Nidumolu, S. R. (1998). A feedback model to understand information system usage. Information \& Management, 33, 213-224. https://doi.org/10.1016/S0378-7206 (98)00026-3

Baleghi-Zadeh, S., Ayub, A. F. M., Mahmud, R., \& Daud, S. M. (2017). The influence of system interactivity and technical support on learning management system utilization. Knowledge Management and E-Learning, 9(1), 50-68. https://www.researchgate.net/publication/316009636_The_influence_of_system_interactivity_and_technical_support_o n_learning_management_system_utilization/citations

Davis, F. D. (1989). Perceived usefulness, perceived ease of use, and user acceptance of Information Technology. MIS Quarterly, 13(3), 319-340. DOI: 10.2307/249008

Davis, F.D., Bagozzi, R.P., \& Warsaw, P.R. (1989). User acceptance of computer technology: a comparison of two theoretical models. Management Science, 35(8), 982-1003. DOI: 10.1287/mnsc.35.8.982

Fathema, N., Shannon, D., \& Ross, M. (2015). Expanding The Technology Acceptance Model (TAM) to examine faculty use of Learning Management Systems LMSs in Higher Education Institutions. Journal of Online Learning and Teaching, 11(2), 210-233. http://jolt.merlot.org/Vol11no2/Fathema_0615.pdf

Kim, M., \& E-Hunter, J. (1993). Relationships among attitudes, behavioral intentions, and behavior: A metaanalysis of past research, part 2. Sage Publications, 20(3), 331-364. http://dx.doi.org/10.1177/009365093020003001

Malaysian Ministry of Education. (2003). Syllabus of Malay Language in Primary Schools [Malay language]. Curriculum Development Centre, Kuala Lumpur.

Finance ministry malaysia. (2014). Feedback on Auditor General's Report Series 3 of 2013. Malaysia.

May, C. Lo, Ramayah, T., \& Abang Azlan Mohamad. (2015). Does intention really lead to actual use of technology? A study of an E-learning system among university students in Malaysia. Croatian Journal of Education, 17(3), 835-853. https://doi.org/10.15516/cje.v17i3.1085

Mohamed Yeou. (2016). An Investigation of students' acceptance of Moodle in a Blended Learning setting using Technology Acceptance Model. Journal of Educational Technology Systems, 44(3), 300-318. https://doi.org/10.1177/0047239515618464

Moya, M., Nabafu, R., Maiga, G., \& Mayoka, K. (2016). Attitude and behavioral intention as mediators in adoption of E-Tax Services in Ura, Uganda. The Operation Research Society of East Africa Journal, 6(1), 157-189. http://journals.udsm.ac.tz/index.php/orsea/article/view/849

Rienties, B., Giesbers, B., Lygo-Baker, Simon; Ma, Hoi Wah Serena, \& Rees, R. (2016). Why some teachers easily learn to use a new virtual learning environment: A technology acceptance perspective. Interactive, 24(3), 539-552. https://doi.org/10.1080/10494820.2014.881394

Saiful Afzan Baru, Lazim Abdullah, Azwadi Alif, \& Hafiz Yusoff. (2014). Modeling of student acceptance of the Virtual Learning Environment (VLE). Journal Business and Social Development, 2 (2), 36-47. https://dokumen.tips/documents/pemodelan-penerimaan-pelajar-terhadap-persekitaran-pembelajaran-maya-vle.html Siti Tutik Muntianah, Endang Siti Astuti \& Devi Farah Azizah. (2012). The Influence of Interest in Behavior Against Actual Use of Information Technology Using the Technology Acceptance Model (TAM) Approach (Case Study of Student Learning Activities in the Faculty of Administrative Sciences, Brawijaya University Malang). Business Administration Journal, 6 (1), 88-97. http://repository.ub.ac.id/id/eprint/114971

Sumak, B., \& Sorgo, A. (2016). The acceptance and use of interactive whiteboards among teachers : Differences in UTAUT determinants between pre- and post-adopters. Computers in Human Behavior, 64, 602-620. https://doi.org/10.1016/j.chb.2016.07.037

Syahid Farid. (2016). A model for e-learning system with quality assessment emphasis in Pakistan. Unpublished Doctorat Dissertation. University of Malaya.

Teo, T., \& Zhou, M. (2016). The influence of teachers' conceptions of teaching and learning on their technology acceptance. Interactive Learning Environments, 52(2), 302-312. https://doi.org/10.1080/10494820.2016.1143844

Tezci, E. (2010). Attitudes and knowledge level of teachers in ICT use: The case of Turkish teachers. Journal of Human Sciences, 7(2), 19-44. http://www.acarindex.com/dosyalar/makale/acarindex-1423936485.pdf 
Wong, Gary, K.W. (2016). The behavioral intentions of Hong Kong primary teachers in adopting educational technology. Educational Technology Research and Development, 64(2), 313-338. DOI: 10.1007/s11423-016-9426-9 Yanti, Setiawan, Nurhabibah \& Yannuar. (2018). Teacher's Perception about the use of elearning/Edmodo in educational activities. In. IOP Conference Series: Materials Science and Engineering, 36 (p.1-4). IOP Publishing. 